\title{
Efficiency of the photosynthetic apparatus of Myriophyllum spicatum L. under anthropopression - a case study from Upper Silesian
}

\author{
Ewelina Roszkowska \\ Faculty of Biology and Environmental Protection, University of Silesia in Katowice \\ ul. Jagiellońska 28, 40-032 Katowice, Poland \\ roszkowska.ewelina@gmail.com• ORCID: 0000-0001-9797-5901
}

\begin{abstract}
The current type of global economy and environmental management requires a change in its approach to the use of natural resources in order to meet human needs. A system approach and an analysis of the importance of anthropogenic ecosystems appears to be an effective tool for sustainable development of urban and post-industrial areas. One example of anthropogenic ecosystems are mining water reservoirs, formed in the basins of subsidence, affecting the increase of biodiversity in the area poor in the surface water reservoirs.

This study presents analysis of the impact of water quality in anthropogenic reservoirs on the Myriophyllum spicatum L. photosynthetic apparatus efficiency. Five reservoirs with different water quality were analysed. The photosynthetic apparatus performance of macrophytes was measured using the chlorophyll fluorescence signal through a Pocket PEA fluorimeter. The results showed that electron transport decreased with deteriorating water quality of reservoirs. This leads to a weakening of the population of Myriophyllum spicatum, which, as a further consequence, may lead to an acceleration of eutrophication of reservoirs.
\end{abstract}

\section{Keywords}

efficiency of the photosynthetic apparatus, sustainable development, ecosystem services, anthropogenic ecosystems, mining subsidence reservoirs

\section{Introduction}

The development of human civilization has left its mark on the state of the Earth's ecosystems. Humans use natural resources regardless of the consequences and pressures we put on the environment. First publications and scientific studies questioning the current model of development and indicating global threats resulting from it have appeared in the sixties the previous century (Skowroński 2006). It became obvious that continuing the current pattern of economic development, based on extensive use of the natural resources, must lead to the inevitable catastrophe on a global scale in the economic, ecological and social spheres. All these spheres are interdependent phenomena, which determines the need to solve problems on the path of sustainable. The approach based on the concept of sustainable development currently is going through a crisis. It is considered that in the longterm perspective, limited natural resources and the restricted adaptation possibilities of 
ecosystems to environmental changes resulting from anthropopresion, economic growth will encounter environmental boundaries, therefore, the concept of sustainable development is contradictory with expected economic growth (Lippert, 2004: 23). And it does not fulfill the functions for which it was accepted and its aim is to provide human civilization with a level of comfort that is rich in the world considered it appropriate (Kingsnorth 2012). In the face of threats facing mankind a change in the approach to the economy seems to be necessary. The approach that will take into account the current state of ecosystems, their adaptability, and the measurable benefits or lack of them resulting from human pressure seems to be appropriate for the present time. A systemic approach, taking into account various environmental, social and economic aspects, seems to be a tool for environmental protection through the valuation of individual services and ecosystem services. An analysis of the impact and environmental pressure based on specific amounts can reach the part of society that managing the global economy (Kronenberg, Lida 2011: 71-72).

Therefore, studies of the dependence of the individual elements of ecosystems on their functions and services are an important element of integrated environmental management. The paper presents a case study of the performance of the photosynthetic apparatus of macrophytes immersed in water on the functions of aquatic ecosystems. The Upper Silesian region is a perfect experimental field showing the impact of the industrial revolution and an economy focused on continued growth on the condition of the natural environment as well as the region of the local population (Woźniak et al. 2018: 172). The mining industry is this kind of economic activity that causes far-reaching modifications of the natural environment. Most of them have a negative impact on both the environment and health and life of residents. A specific case is the emergence of new habitats in places where previously there were no natural conditions for their creation such as the anthropogenic reservoirs formed in the basins of settling as a result of underground exploitation of hard coal or zinc and lead ores. Thanks to this, new niches, settled by numerous species of plants and animals, are created. Area poor in natural water reservoirs, because of its history, it gains access to new benefits. Apart from natural and functional roles, subsidence reservoirs perform recreational, fire and cooling functions as well as a source of water supply.

The area poor in terms of species and ecosystem diversity, heavily urbanized, acquired new properties as a result of subsidence, was enriched in a new ecosystem? which becomes an „environmental island” within which there are different habitat conditions compared to the surrounding areas (Sierka et al. 2012: 17). The ongoing process of succession makes the areas of the former land gradually become similar to natural lakes (Stalmachová and Sierka 2014: 45-46, Sierka et al. 2018: 64). Subsequent subsidence settlements combine ecological dependencies, according to which all plants and animals play an important role in nature. Leaving, without significant human interference, the reservoirs created in the subsidence basins contribute to the emergence of new ecosystems, but species similar to naturally existing ones, allow the development of sustainable and valuable biocoenoses related to the aquatic environment, which has a large and beneficial effect on the alternative management of mining damage areas. In addition, these reservoirs constitute a reservoir of drinking water, flood protection, are fisheries for anglers, play recreational and cultural roles (Sierka et al. 2012: 17-29). Based on the case study, it was found that the performance of the photosynthetic apparatus of macrophytes immersed in water is related to the ecological state of the reservoirs, and thus results from the way they are used and managed. The efficiency of the photosynthetic apparatus of macrophytes, in reservoirs with good ecological status, indicates 
the most efficient use of solar energy, which affects the production of plant biomass, and further, the development of herbivorous macroinvertebrates, fish, inhibition of the growth of green algae or the absorption of more nutrients, which slows down the eutrophication process (Pierzchała et al. 2016: 278).

The aim of this paper is determination of anthropopresion impact on photosynthesis efficiency of Myriophyllum spicatum L. in anthropogenic reservoir ecosystems in urban and industrial areas.

\section{Materials and methods}

The research was carried out using the case study method. Five mining subsidence water reservoirs were selected located on the Katowice Upland according to the geographical breakdown of Poland (Solon et al. 2018: 159). All reservoirs are located in the urban area and have the same genesis.

Reservoir No. 1 Czarny Staw (50¹4'13.3”N $\left.18^{\circ} 55^{\prime} 58.0^{\prime \prime} \mathrm{E}\right)$ is located in Katowice surrounded by a forest complex: Panewnickie Forests. (Fig. 1A). Czarny Staw is characterized by the highest water transparency, well-developed rush vegetation with a lesser bulrush (Typha angustifolia L.) and common rush (Juncus effusus L.) from the south, west and north side and a sandy and stony bank on the eastern side. Among the water vegetation, the Eurasian watermilfoil dominates. The reservoir is a habitat for many species of animals, including breeding birds. Reservoir performs also a recreational functions. Otherwise, this reservoir is a reservoir of water for nearby breeding ponds, which means that the water level is subject to frequent fluctuations.

Reservoir No. 2 Zapadlisko (50 09'42.2"N $19^{\circ} 00^{\prime} 11.2$ "E) is located in Tychy surrounded by a forest complex, two other water reservoirs and the allotment gardens (Fig. 1B). It is characterized by welldeveloped shore and rush vegetation from the south-west side and the hardened shore of the flaming rock on the north and east.
Reservoir No. 3 Staw Leśny (50 12 ' 48.9”N $\left.18^{\circ} 42^{\prime} 08.9^{\prime \prime} \mathrm{E}\right)$ is located in Knurów surrounded by a forest complex, fields, wasteland and the railway line (Fig. $1 \mathrm{C}$ ).

Reservoir No. 4 Zawalisko (50¹9'54.1'N $18^{\circ} 47^{\prime} 24.3^{\prime \prime} \mathrm{E}$ ) is located in Zabrze surrounded by the fields, wasteland, another reservoirs and residential buildings of the Mikulczyce district (Fig.1D). The place is used by the local community as a park. The reservoir is quite shallow, characterized by well-developed aquatic vegetation, the main component of which is Myriophyllum spicatum.

Reservoir No. 5 Martyn ( $50^{\circ} 17^{\prime} 44.3^{\prime \prime} \mathrm{N}$ $\left.18^{\circ} 53^{\prime} 30.6^{\prime \prime} \mathrm{E}\right)$ is located in Świętochłowice surrounded by Cross-town express road, wasteland, heaps and a gas station (Fig. 1E). Despite this, a small area of shelter and shrubbery makes the reservoir an enclave for many plant and animal species.

The study of physicochemical properties of water and the efficiency of the photosynthetic apparatus of the Eurasian watermilfoil (Myriophyllum spicatum L.) was carried out in 2017 from June to October. The samples were collected once a month from each reservoir at five points (from different sides of the tank). The photosynthetic apparatus performance of macrophytes was measured using the chlorophyll fluorescence signal after 30 min dark adaptation, through a Pocket PEA fluorimeter (Hansatech Instruments Ltd.). The obtained data was analyzed using the Pocket PEA Plus V1.10 software (Hansatech Instruments Ltd.). On the basis of the obtained results, the OJIP test was performed and Kautsky fluorescence induction curves were prepared. Dissolved oxygen (DO), conductivity, salinity, total dissolved solids (TDS), $\mathrm{pH}$, and water temperature were measured using the YSI Professional plus multiparameter probe. The chlorophyll $a$ content in water was measured by spectrophotometric method. 

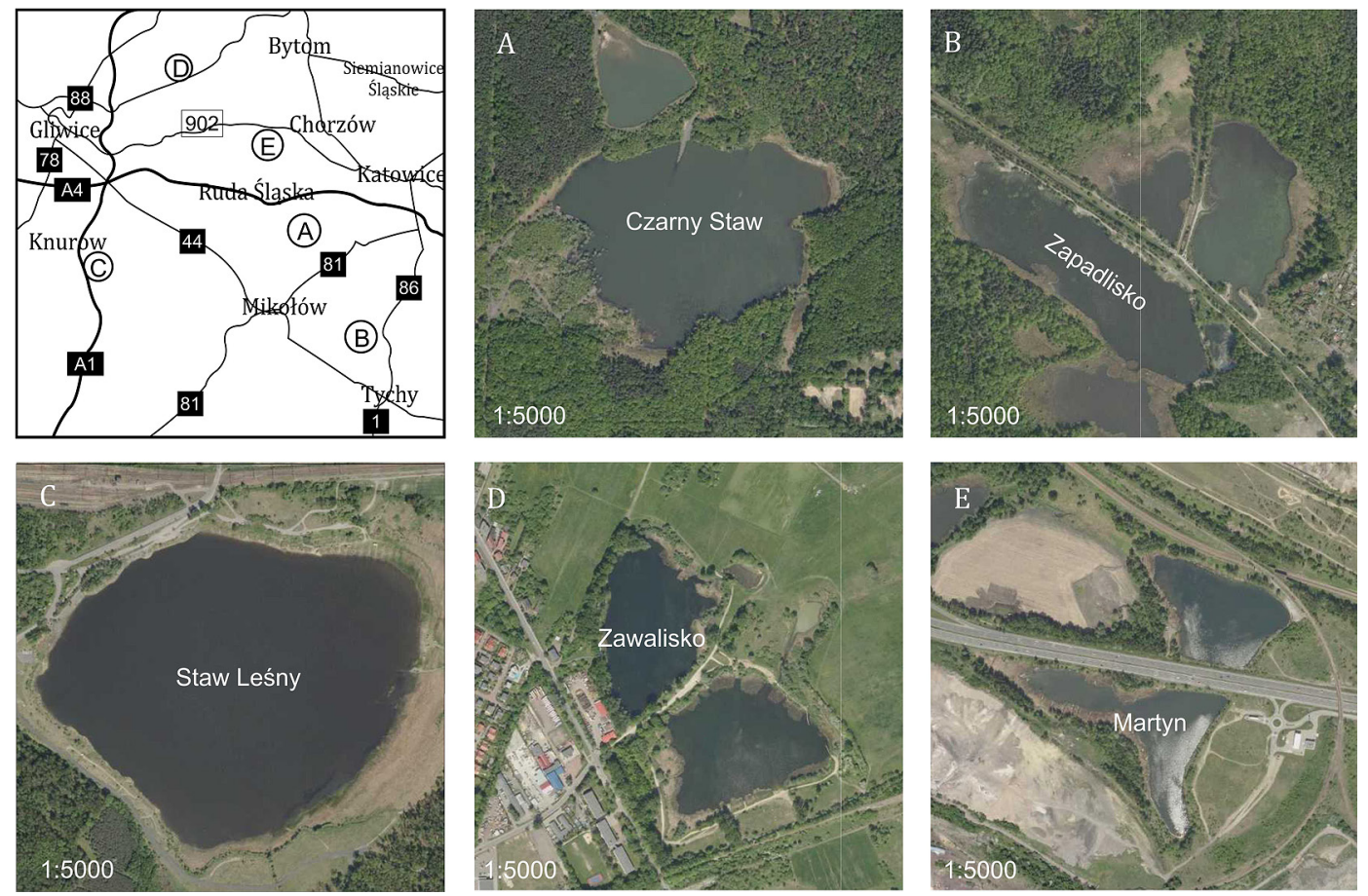

Fig. 1. Location of the tested mining subsidence water reservoirs A: Reservoir No. 1 - Czarny Staw, B: Reservoir No. 2 - Zapadlisko, C: Reservoir No. 3 - Staw Leśny, D: Reservoir No. 4 - Zawalisko, E: Reservoir No. 5 - Martyn. Photos from A-E are fragments of an orthophotomap in the scale 1:50oo (www.geoportal.gov.pl - changed)

\section{Results}

The analysis of chlorophyll fluorescence and physicochemical properties of water in the tested reservoirs allowed us to compare the water quality in reservoirs and refer them to the macrophyte chlorophyll fluorescence induction curves. The reservoirs differ in terms of the ecological status of the ecosystem, physico-chemical parameters such as transparency, $\mathrm{pH}$, total dissolved solids (TDS), dissolved oxygen (DO) and also vegetation and the type of development of adjacent areas. Czarny Staw is characterized by the lowest content of chlorophyll $a$ in water, the lowest conductivity and TDS. Zapadlisko has the highest $\mathrm{pH}$ (8.19), the lowest salinity and TDS. The Staw Leśny is characterized by the highest content of chlorophyll $a, \mathrm{pH}$ slightly acidic (6.83 units) and the highest degree of salinity, TDS, conductivity and lowest level of dissolved oxygen (tab. 1).
Individuals existing in Czarny Staw are characterized by the largest size of the electron transport acceptors of PS II (area), maximal fluorescence $(\mathrm{Fm})$ and variable fluorescence $(\mathrm{Fv})$. In case of reservoirs no. 1, 2, 4 and 5 fluorescence chlorophyll curve do not show significant differences at steps $\mathrm{O}$ and $\mathrm{J}$ however, steps I and $\mathrm{P}$ are getting lower and lower in subsequent reservoirs (fig. 2). In reservoir no. 3 (Staw Leśny) the entire course of the chlorophyll $a$ transient curves is at a clearly lower level than in case the other reservoirs (fig. 2).

The maximum quantum yield of PS II $\left(\mathrm{F}_{\mathrm{v}} /\right.$ $\mathrm{F}_{\mathrm{m}}$ ) is similar for individuals inhabiting all tested reservoirs. However, Myriophyllum spicatum inhabiting reservoir no. 1 is characterized by the highest vitality of PS II (PI). In addition, these individuals absorb the most energy of light, and therefore more energy is bound $\left(\mathrm{TR}_{\mathrm{o}}\right)$ and used for 
Table 1. The averaged physical and chemical parameters of mining subsidence water reservoir. Chl $a-$ chlorophyll content in water, Temp. - water temperature, Cond - conductivity, Sal - salinity, TDS - total dissolved solids, DO - dissolved oxygen

\begin{tabular}{lccccccc}
\hline \multicolumn{1}{c}{ Reservoir } & Chla & Temp $\left({ }^{\circ} \mathrm{C}\right)$ & $\mathrm{pH}$ & Cond $\left(\mathrm{mS} \cdot \mathrm{cm}^{-1}\right)$ & Sal $(\mathrm{ppt})$ & TDS $\left(\mathrm{g} \cdot \mathrm{l}^{-1}\right)$ & DO $\left(\left.\mathrm{mg} \cdot\right|^{-1}\right)$ \\
\hline Czarny Staw & 1.855 & 11.055 & 7.502 & 1.526 & 1.854 & 1.784 & 11.266 \\
Zapadlisko & 2.054 & 12.026 & 8.193 & 2.422 & 1.294 & 1.523 & 11.327 \\
Staw Leśny & 3.954 & 11.004 & 6.826 & 2.523 & 2.000 & 1.984 & 8.256 \\
Zawalisko & 3.375 & 10.027 & 7.253 & 2.485 & 1.935 & 1.593 & 11.935 \\
Martyn & 2.936 & 10.045 & 7.662 & 2.454 & 1.653 & 1.948 & 11.383 \\
\hline
\end{tabular}

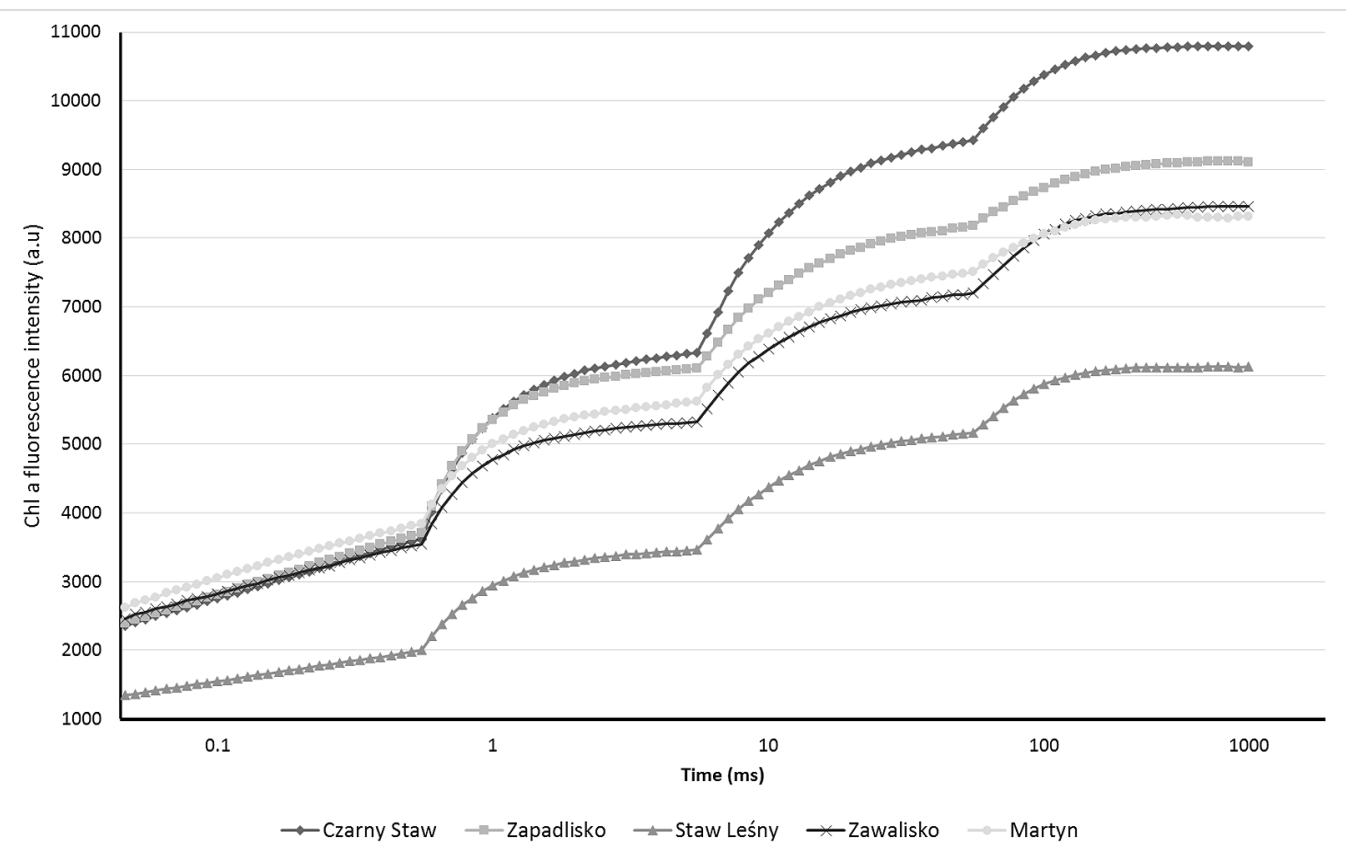

Fig. 2. Chlorophyll $a$ fluorescence OJIP transient curves in Myriophyllum spicatum leaf in different mining subsidence water reservoirs. Each step in figure indicates the minimal fluorescence intensity when all PS II reaction centers (RC) are open (the $\mathrm{O}$ step), the intensity at o,3 $\mathrm{ms}$ (the $\mathrm{K}$ step), the intensity at $2 \mathrm{~ms}$ (the J step), the intensity at $30 \mathrm{~ms}$ (the I step), and the maximal intensity when all PS II RCs are closed (the P step)

electron transport $\left(\mathrm{ET}_{\mathrm{o}}\right)$ which results in a more efficient bright photosynthesis phase. Reservoir no. 3 (Staw Leśny) and 5 (Martyn) have the lowest vitality of PS II. For reservoirs No. 2, 3, 4, and 5, absorption (ABS) and dissipation (DI) of light energy is on a similar level but individuals colonizing reservoir no. 3 (Staw Leśny) are characterized by the lowest amount of bound energy (TR) and used for electron transport (ET) as well as the lowest rate of electron reduction reducing PSI (RE) which proves the low performance of the photosynthetic apparatus (tab. 2).

\section{Discussion}

OJIP parameters can be used to identify sensitive functions such as energy absorption, energy trapping, and electron transport in PSII and PSI; therefore, the OJIP-test 
Table 2. Selected parameters of the Myriophyllum spicatum photosynthetic apparatus efficiency in the tested reservoirs. (Averaged value from 50 measurements). PI - performance index (index of photosystem II vitality), $F_{v} / F_{m}$ - Maximal quantum yield of PSII, ABS/CS - absorption flux per CS (excited cross section), $\mathrm{TR}_{\mathrm{o}} / \mathrm{CS}$ - trapped energy flux per CS, $\mathrm{ET}_{\mathrm{o}} / \mathrm{CS}$ - electron transport flux per CS, $\mathrm{DI}_{\mathrm{o}} / \mathrm{CS}$ - dissipated energy flux per CS, $\mathrm{RE}_{\mathrm{o}} / \mathrm{CS}$ - reduction flux of the final PSI electron acceptors per CS. Markings $o$ and $m$ means parameter - at orgin $\left(F_{o}\right)$ and maximum $\left(F_{m}\right)$ fluorescence

\begin{tabular}{|c|c|c|c|c|c|c|c|}
\hline \multirow{2}{*}{ Reservoir } & \multirow{2}{*}{ PI total } & \multirow{2}{*}{$\mathrm{F}_{\mathrm{v}} / \mathrm{F}_{\mathrm{m}}$} & $\mathrm{ABS} / \mathrm{CS}_{0}$ & $\mathrm{DI}_{0} / \mathrm{CS}_{0}$ & $\mathrm{TR}_{0} / \mathrm{CS}_{0}$ & $\mathrm{ET}_{0} / \mathrm{CS}_{0}$ & $\mathrm{RE}_{0} / \mathrm{CS}_{\mathrm{c}}$ \\
\hline & & & $\mathrm{ABS} / \mathrm{CS}_{\mathrm{m}}$ & $\mathrm{DI}_{0} / \mathrm{CS}_{\mathrm{m}}$ & $\mathrm{TR}_{0} / \mathrm{CS}_{\mathrm{m}}$ & $\mathrm{ET}_{\mathrm{o}} / \mathrm{CS}_{\mathrm{m}}$ & $\mathrm{RE}_{0} / \mathrm{CS}_{\mathrm{n}}$ \\
\hline \multirow{3}{*}{ Czarny Staw } & \multirow{3}{*}{3.63} & \multirow{3}{*}{0.73} & 1090.01 & 273.34 & 816.67 & 423.94 & 122.02 \\
\hline & & & & & & & \\
\hline & & & 4536.79 & 1090.01 & 3446.78 & 1827.18 & 526.64 \\
\hline \multirow{3}{*}{ Zapadlisko } & \multirow{3}{*}{2.81} & \multirow{3}{*}{0.64} & 581.11 & 206.78 & 474.85 & 247.44 & 84.95 \\
\hline & & & & & & & \\
\hline & & & 1679.88 & 581.11 & 1775.31 & 943.15 & 324.24 \\
\hline \multirow{3}{*}{ Staw Leśny } & \multirow{3}{*}{1.87} & \multirow{3}{*}{0.71} & 660.31 & 185.46 & 374.33 & 164.92 & 49.01 \\
\hline & & & & & & & \\
\hline & & & 2435.62 & 660.31 & 1098.77 & 493.37 & 142.96 \\
\hline \multirow{3}{*}{ Zawalisko } & \multirow{3}{*}{2.26} & \multirow{3}{*}{0.69} & 648.2 & 190.07 & 458.13 & 239.42 & 81.17 \\
\hline & & & & & & & \\
\hline & & & 2310.19 & 648.2 & 1661.99 & 891.56 & 300.85 \\
\hline \multirow{3}{*}{ Martyn } & \multirow{3}{*}{1.68} & \multirow{3}{*}{0.72} & 738.16 & 203.27 & 534.89 & 292.71 & 104.16 \\
\hline & & & & & & & \\
\hline & & & 2745.74 & 738.16 & 2007.58 & 1111.63 & 397.89 \\
\hline
\end{tabular}

approach has been used in various areas of plant biology to understand the responses of the photosynthetic apparatus to different environmental conditions (Strasser et al. 2000: 470, 2004: 332). The OJ phase $(\mathrm{o}-3 \mathrm{~ms})$ is called the photochemical phase because its kinetics depends strongly on the light intensity (Strasser et al. 1995: 34). It proves similar light conditions for reservoirs No. 1, 2, 4 and 5. Differences in the subsequent phases of the curve indicate the occurrence of stressors affecting the reduction of the plastoquinone (PQ) pool (the JI phase) (Tóth et al. 2007: 196) and reduction of ferredoxin in the presence of inactive ferredoxin: NADP+ oxidoreductase (the IP phase) (Schansker et al. 2005: 258). The completely different course of the curve in the case of reservoir No. 3 shows the lower intensity of light reaching the macrophytes and the occurrence of stressors that negatively affect the overall performance of the photosynthetic apparatus. The presence of point $\mathrm{K}$ indicates irregularities in the course of the process during 200-300 $\mu \mathrm{s}$ after exposure. Which suggests the presence of abiotic stressors interfering with electron transport in PSII in all tested reservoirs. This also confirms by the maximum quantum efficiency of PS II $(\mathrm{Fv} / \mathrm{Fm})$. This parameter is similar for individuals inhabiting all tested deposits. However, these parameters assume a value of 0.85 , under optimal conditions. Lower values of this parameter indicate the presence 
of different biotic or abiotic stressors. Energy pipeline models have indicated that several sites in PS II are sensitive to various types of environmental stress (Mehta et al. 2010:17, Kalaji et al. 2011: 68-69, Gautam et al. 2014: 534-535). In our study, energy pipeline models were used to indicate the active and inactive sites in phenomenological fluxes per $\mathrm{CS}_{\mathrm{o}}\left(\mathrm{ABS} / \mathrm{CS}_{\mathrm{o}}, \mathrm{TR}_{\mathrm{o}} / \mathrm{CS}_{0}, \mathrm{DI}_{\mathrm{o}} / \mathrm{CS}_{\mathrm{o}}\right.$, and $\mathrm{ET}_{\mathrm{o}} /$ $\left.\mathrm{CS}_{\mathrm{o}}\right)$ and $\mathrm{CS}_{\mathrm{m}}\left(\mathrm{ABS} / \mathrm{CS}_{\mathrm{m}}, \mathrm{TR}_{\mathrm{o}} / \mathrm{CS}_{\mathrm{m}}, \mathrm{DI}_{\mathrm{o}} / \mathrm{CS}_{\mathrm{m}}\right.$, and $\mathrm{ET}_{\mathrm{o}} / \mathrm{CS}_{\mathrm{m}}$ ) (tab. 2). Our results showed that $\mathrm{TR}_{\mathrm{o}}$ and $\mathrm{ET}_{\mathrm{o}}$ decreased with decreasing water quality. In such conditions active reaction centers (RCs) are converted into inactive RCs, which reduces the energy trapping efficiency and electron transport from PS II in reservoirs with stronger anthropopressure and leads to a weakening of the population of Myriophyllum spicatum. In a further consequence, it may affect the increase of the amount of the biogenic nutrients, the increase of phytoplankton, and the acceleration of eutrophication of reservoirs.

It can be said that the water quality affects the condition of the ecosystem causing disturbances in the physiological processes of macrophytes inhabiting these ecosystems. Weakening of the Eurasian watermilfoil population can cause a knock-on effect for other elements of the ecosystem resulting from the functions of macrophytes in the proper and stable functioning of water ecosystems, especially in areas transformed by human activities. What can significantly affect the impoverishment of the environment and value of the areas. Mining subsidence reservoirs are an important element from the perspective of economics and development of cities and industrial areas, especially in areas that are poor in natural resources of surfaces water.

Except for contributing to a greater diversity of species, biocenoses and landscape in these areas, mining subsidence reservoirs, especially well-functioning are attractive places for rest and recreation of the local population as well as positively effect on microclimate.

\section{References}

Bohdanowicz J., 2001, Ku cywilizacji ekorozwoju, Gdańsk, 29, 155-158.

Gautam A., Agrawal D., SaiPrasad S. V., Jajoo A., 2014, A quick method to screen high and low yielding wheat cultivars exposed to high temperature, Physiol. Mol. Biol. Plants, 20, 533-537.

Kalaji H.M., Govindjee Bosa K., Kościelniak J., ŻukGołaszewska K., 2011, Effects of salt stress on photosystem II efficiency and $\mathrm{CO}_{2}$ assimilation of two Syrian barley landraces, Environ. Exp. Bot.,73, 64-72.

(WEB-01) Kingsnorth P., 2012, Confessions of a recovering environmentalist, Orion Magazine, January/ February. Retrieved from https://orionmagazine. org/article/confessions-of-a-recovering-environmentalist, dostęp 1.02.2019.

Kronenberg J., Lida N., 2011, Simple Living and Sustainable Consumption. Problemy Ekorozwoju Problems of Sustainable Development, 6, 2, 67-74.

Lippert I., 2004, An Introduction to the Criticism on Sustainable Development. Germany, Brandenburg University of Technology, 1-40.

Mehta P., Jajoo A., Mathur S., Bharti S., 2010, Chlorophyll a fluorescence study revealing effects of high salt stress on Photosystem II in wheat leaves, Plant Physiol. Biochem., 48, 16-20.

Pierzchała Ł., Sierka E., Trząski L., Bondaruk J., Czuber B., 2016, Evaluation of the suitability of anthropogenic reservoirs in urban space for ecological restoration using submerged plants (Upper Silesia, Poland), Appl. Ecol. Env. Res., 14, 1, 277-296. Schansker G., Tóth S.Z., Strasser R.J., 2005, Methylviologen and dibromothymoquinone treatments of pea leaves reveal the role of photosystem I in the Chl a fluorescence rise OJIP. Biochim. Biophys. Acta, 1706, 250-261.

Sierka E., Roszkowska E., Woźniak G., 2018, Znaczenie wody dla funkcjonowania ekosystemów na terenach miejsko-przemystowych (Water importance to functioning of ecosystems in urban-industrial areas), Aktualne Problemy Gospodarki Wodnej. Monografie Śląskiego Centrum Wody, 1, 59-70.

Sierka E., Stalmachova B., Molenda T., Chmura D., Pierzchała Ł., 2012, Environmental and socio-economic importance of mining subsidence reservoirs, Technicka Literatura BEN, Praha, 128. 
Skowroński A., 2006, Sustainable development as the perspective offurther civilisation development, Problemy Ekorozwoju, 1, 2, 47-58.

Solon, J., Borzyszkowski J., Bidłasik M., Richling A., Badora K., Balon J., Brzezińska-Wójcik T., Chabudziński Ł., Dobrowolski R., Grzegorczyk I., Jodłowski M., Kistowski M., Kot R., Krąż P., Lechnio J., Macias A., Majchrowska A., Malinowska E., Migoń P., Myga-Piątek U., Nita J., Papińska E., Rodzik J., Strzyż M., Terpiłowski S., Ziaja W., 2018, Physico-geographical mesoregions of Polandverification and adjustment of boundaries on the basis of contemporary spatial data, Geographia Polonica, 91, 2, 143-168.

Stalmachová B., Sierka E., 2014, Managed succession in reclamation of postmining landscape, Technická univerzita v Košiciach, Košice, 85 .

Strasser R.J., Srivastava A., Govindjee G., 1995, Polyphasic chlorophyll a fluorescence transient in plants and cyanobacteria, Photochem. Photobiol., 61, 32-42.
Strasser R.J., Srivastava A., Tsimilli-Michael M., 200o, The fluorescence transient as a tool to characterize and screen photosynthetic samples, in: Yunus M., Pathre U., Mohanty P. (eds.), Probing Photosynthesis: Mechanisms, Regulation and Adaptation, Taylor \& Francis Publishers, London, 445-483.

Strasser R.J., Tsimilli-Michael M., Srivastava A., 2004, Analysis of the chlorophyll a fluorescence transient, in: Papadogeorgiou G.C., Govindjee (eds.), Chlorophyll a Fluorescence: A Signature of Photosynthesis, Springer, The Netherlands, 321-362.

Tóth S.Z., Schansker G., Strasser R.J., 2007, A non-invasive assay of the plastoquinone pool redox state based on the OJIP-transient, Photosynth. Res., 93, 193-203.

Woźniak G., Sierka E., Wheeler A., 2018, Urban and Industrial Habitats: How Important They Are for Ecosystem Services, in: Ecosystem Services and Global Ecology, IntechOpen, 169-192.

\section{Wydajność aparatu fotosyntetycznego Myriophyllum spicatum L. w warunkach antropopresji - studium przypadku z Górnego Śląska}

\section{Streszczenie}

Obecny typ globalnej gospodarki i zarządzania środowiskiem wymaga zmiany podejścia do wykorzystania zasobów naturalnych w celu zaspokojenia ludzkich potrzeb. Systemowe podejście i analiza znaczenia ekosystemów antropogenicznych wydaje się być dobrym narzędziem zrównoważonego rozwoju obszarów miejskich i poprzemysłowych. Jednym z przykładów ekosystemów antropogenicznych są zbiorniki wodne, powstałe w nieckach osiadania, przyczyniające się do wzrostu bioróżnorodności na obszarach ubogich w zbiorniki wód powierzchniowych.

W pracy przedstawiono analizę wpływu jakości wody w zbiornikach antropogenicznych na wydajność aparatu fotosyntetycznego Myriophyllum spicatum L. Zbadano pięć zbiorników o różnej jakości wody. Wydajność aparatów fotosyntetycznych makrofitów mierzono za pomocą sygnału fluorescencji chlorofilu za pomocą fluorymetru Pocket PEA. Wyniki pokazały, że transport elektronów zmniejszał się wraz z pogarszającą się jakością wody w zbiornikach. Prowadzi to do osłabienia populacji Myriophyllum spicatum, a w dalszej konsekwencji może spowodować przyspieszenie eutrofizacji zbiorników.

\section{Stowa kluczowe}

Wydajność aparatu fotosyntetycznego, zrównoważony rozwój, usługi ekosystemowe, ekosystemy antropogeniczne, zbiorniki powstałe w nieckach osiadania 